\title{
Driving forces for innovation: are they measurable?
}

\section{Maria Teresa De Noronha Vaz* and Marisa Cesário}

\author{
Faculty of Economics, \\ University of Algarve, \\ Campus de Gambelas, \\ 8000 Faro, Portugal \\ E-mail:mtvaz@ualg.pt E-mail: mcesario@ualg.pt \\ *Corresponding author
}

\begin{abstract}
This paper outlines a synthetic framework based on the concept of the learning process as a driver to redress stakeholders' attitudes and strategic choices. The discussion is focused on the advantages that may result from institutional proximity, knowledge diffusion and coordination for the specific building up of a territorial knowledge base and the consequent achievement of sustainable regional development. This theoretical framework is applied to an empirical exercise identifying a number of variables supposed to be able to characterise firms and regional performances towards different forms of innovation. Modelling techniques are used to demonstrate that firms' capacity to innovate is a complex attribute whose determinants change. The results permit to conclude causal links that may be useful for a better understanding of innovation and as support instruments for policy-makers which intend to search for specificities in the regional development process.
\end{abstract}

Keywords: determinants of innovation; development conditions; technological learning; institutional proximity; entrepreneurial strategy; innovative behaviour.

Reference to this paper should be made as follows: De Noronha Vaz, M.T. and Cesário, M. (2008) 'Driving forces for innovation: are they measurable?', Int. J. Foresight and Innovation Policy, Vol. 4, Nos. 1/2, pp.30-50.

Biographical notes: Maria Teresa De Noronha Vaz is Professor of Regional Economics, and Economics of Innovation at the Faculty of Economics, University of Algarve, Portugal. She has an academic career stretching across Europe, having worked as Fellow or Visiting Professor in Germany, Spain, France, Belgium, Russia and Brazil. Her recent research has taken her in the direction of innovation and local development, particularly analysing the impact of SMEs in spatial dynamics. She has been co-coordinator of European, national and local founded projects as well as being involved in many other projects. So far she has edited several books related to innovation in small firms and rural development and published an extensive amount of scientific material related to the agro-food sector and regional economics. The emphasis has been put in the use of instruments to implement innovation in lagging areas.

Marisa Cesário is a Lecturer of Microeconomics in the University of Algarve, Portugal. She is presently developing her $\mathrm{PhD}$ research dealing with technology-related strategies in labour-intensive industries, with special attention to correlated consequences for local employment. She has published the results of her work in international reviews, such as the European Planning Studies, the International Journal of Foresight and Innovation Policy or the New MEDIT Journal. 


\section{Introduction}

Facing a situation of enlargement within a globalisation context, the European goal of cohesion stresses some of the concerns related to regional asymmetries in a context of differentiated integration. The need for acceptance of different development opportunities for the European regions and their stakeholders also imposes the application of dynamic forms of interdependent adjustments. Thus, convergence at the macroeconomic level is expected, institutional coordination is required and stakeholders' apprenticeship is required in order to integrate production, consumption and distribution in the international networks of technological advances.

According to these conditions, regional activities should undergo pressures, tending to reduce the territorial and consumer specificities. It is within this framing that the strategies of regional development are discussed and formulated, their success depending on the capacity of the locals to absorb changes. The boundary between the policy measures for regional development and the real opportunities for transformation is limited. The many restrictions that are due to stakeholders often characterise regionalreduced capacities and tenuous potential. The success of regional policy is, therefore, mostly dependent on the attitude of stakeholders and their aptitude to integrate the new European challenges (Landabaso, 1997).

Based upon such concerns our work provides several contributions:

1 Firstly, a theoretical framework demonstrates that the learning process is a way to redress stakeholders' attitudes and aptitudes and, consequently, is also a tool for sustainable regional development. While discussing the advantages of institutional proximity, knowledge diffusion and coordination, the links and differences between learning as firms' requirement and learning as regional strategic choices for innovation are observed.

2 The second part of this paper reports an empirical exercise. The assumed hypothesis is that a major output of learning, at regional level, is firms' capacity to innovate. A methodology able to appreciate the behavioural patterns of firms regarding its different determinants is developed.

3 The introduced models add a particular focus to all factors related with learning, and the conclusion supplies several suggestions to policy-makers.

\section{Theoretical framing}

\subsection{Advantages for learning: institutional proximity, knowledge diffusion and coordination}

Space and location are not static components of the development process. They submit constant adaptation to dominant industrial models as an effect of the type of relations among stakeholders. Formally or informally expressed, such social and economic behaviours may be identified. Ménard (2000) called them transactions. External to the markets, internal to the hierarchies or cooperatives, transactions always have an influence on the land use and local development as they are inductive into knowledge and may speed innovative attitudes. 
From this point of view, the introduction of time as a factor of territorial dynamics allows to transform simple relations between the stakeholders into long-lasting partnerships which may create learning requirements, learning procedures or even learning routines. This is why time should be accepted as a natural instrument of development allowing very consistent theoretical approaches about the nature of knowledge creation and its diffusion.

In this context, locals or regions should be perceived as having a historical path from which the institutional context resulted. It serves as a regulator of collective and individual practices, and institutional proximity may favour larger knowledge basis and improve knowledge diffusion. The assumption that the capacity of interaction and cooperation within a certain geographical space (local) and among others result in competitive advantages is a logic sequence. The level of proximity among institutions is documented to be a determinant for regional development and policy. Besides recognising the importance of economic, political and social structures that frame the proximity among institutions, we also admit that stakeholders have a cognitive capacity to strategically interact with their environmental contexts (Clark and Tracey, 2004)

There are discussions evolving from the concepts of geographic and technological proximity. While the first establishes the idea of spatial organisation of the elements (firms and other institutions) and may induce agglomeration economies, the second suggests the interaction between the stakeholders is very often encouraged by the common objectives of the productive branch to which they belong and may imply the achievement of scope advantages. In any case, both concepts should intensify exchanges and flows and ease entrepreneurial activity. Firms' strategic choices for innovation or partnership may change in conformity with the existence, or not, of institutional proximity.

The frequent occurrence of situations with characteristics either of geographic or of technological proximity led the research group GREMI ${ }^{1}$ to the concept of 'innovative environment' from which the theoretical possibilities were brought forward to the discussion of the spatial dynamics phenomenon exclusively based on synergetic movements and innovative forms.

Aydalot (1984) had pointed out a concern related with the inefficiency of the two opposite theses on the convergence or divergence of the growth patterns of different regions. None of them managed to explain the observations that, in the meantime, evidenced well-succeeded cases such as those verified in the regions Emilia Romana, Toscana, south of Germany, south of California, Japan and Silicon Valley. The debate, which was initiated then, brought to the scene the environment supporting the small firms and suggested that the milieu (or environment in which the companies are integrated) should be the basic concept for a new model of regional development.

Camagni (1991) defined the economic space as being "a relational space, the field of social interactions, interpersonal synergies and social collective actions that determine the innovative capability and the economic success of specific local areas". This concept was extended towards a systemic and complex approach grounded on the existence of dynamic processes of learning as development drivers (Grosjean and Crevoisier, 1998). Meanwhile, in Europe evidence proved that, in a context of growing competition, companies and regions may face factors of competitive advantage that, apart from being related with prices, could result from the benefits occurring from the capacity of systematically acquiring new competencies (Gabolde, 1997). Small firms took a major role in this discussion because their embeddedness capability became the main argument 
to explain that when productive structures are linked to the geographical spaces they promote development (De Noronha Vaz, 2004).

Considering that geographical and institutional proximity may influence the different forms of knowledge diffusion, the following questions can be addressed: how can learning be introduced in the territories and how can the space be (re)organised in order to better accept new technological and organisational inputs?

The phenomenon of technological change promoted by innovation is one of the most important issues focused by the literature about growth. However, the static concept of innovation that lays on the linear model science-technology has long been replaced by interactive approaches grounded on the concept of knowledge basis and its diffusion. The new systemic models whose modalities of learning are able to promote knowledge contribute mostly to efficient results in the understanding of innovative aptitudes (Nelson and Winter, 1982, Lundvall, 1992; Lundvall and Johnson, 1994).

The geographic spaces (local or regions) have institutional contexts that either formally or informally favour the exchange between the stakeholders. As learning regions they have the prerequisites for the apprenticeship in their historic-cultural past (Keeble, 1997). But, at present, they assume norms, codes of conduct or conventions identifying an institutional proximity (Storper, 1997; Maillat, 1998; Crevoisier, 2001). Within such a space, collective actions and organised sectorial interdependences perform informal functions such as research, selection, codification, transformation, control and other procedures that, in final outcome, represent created or accumulated knowledge (tacit or codified). When the importance that the tacit knowledge has upon innovation is highlighted, the history of the locals, the institutional governance and the stakeholders' behaviours merge as determinant factors of development and sustainability.

The recognition of these arguments brings some interesting conclusions:

1 The existence of certain geographic spaces especially endowed with institutional contexts is more suitable for knowledge diffusion, namely, tacit. This may explain a possible competitive advantage in their present growth processes.

2 Indecision about tacit knowledge diffusion: will it demand the simultaneous existence of institutional and geographic proximity? Considering that codified knowledge is more mobile, it could be asked if both forms of knowledge, tacit and codified, are so associated that the mobility (or immobility) of one implies the mobility of the other (Amin and Cohendet, 1999; Torre and Gilly, 2000).

In fact, Gallego (2003) presents a gratifying theoretical formulation to explain that tacit knowledge diffusion demands the need of associated forms of geographic and institutional proximity. On this regard, Cooke et al. $(1998 \mathrm{a} ; 1998 \mathrm{~b})$ argue that in spite of the fact that distance is a factor that does not restrain the codified knowledge, only an institutional whole composed of scientific-technological institutions allows a region to develop a regional innovation system able to stimulate sustainable growth forms.

It is worth to refer that in a regional innovation system (a geographic space with a cohesive entrepreneurial structure particularly apt to innovate) innovating and noninnovating companies set together, the leader companies performing the role of new product developers, differentiators and partnership promoters (Gallego, 1997). Such companies induce new forming technological needs through their participation in external networks with others (suppliers or customers) or R\&D centres and interactions that may be based on informal relationships of cooperation, strengthened by the personal 
knowledge and, eventually, favoured by the geographic or even institutional proximity (Torre and Gilly, 2000). In end result, trust is able to hurry and progress tacit knowledge diffusion, which in turn eases the sources of codified knowledge transmission.

But, are these alterations in the knowledge transmission processes sufficient factors to generate new opportunities for structural changes and growth at local level?

\subsection{Advantages for innovation: learning as a firm's requirement and learning within a regional strategic choice}

We believe that an answer to the previous question may be found in the forms how cooperation is developed within the region. The theoretical contribution of Antonelli (1995) allows explaining the origin of cooperation. Due to the existence of complementarities among different production units, the functional division of labour and the desegregation of the productive processes encourage a major specialisation degree, full dependent on interdependencies. Only coordination permits the transmission of relevant information, becoming the only warranty of the productive cycle of the new products. It also allows keeping the information flow safe. It is the ex-ante cooperation that strengthens the concept of networking (Fischer and Johansson, 1993).

Due to the fact that spatial contexts are so diversified, it has not been easy to adapt the reality of the regional productive bases to the earlier concepts. One of the limits was observed by Grosjean and Crevoisier (1998) and regards the fact that most of the available case studies refer to the region as detaining a sole production systems, when the space is rarely homogeneous from a productive point of view. As pointed out by De Noronha Vaz (2007), industrial models coexist in most of the geographical spaces making difficult the implementation of a regional innovation system, for example. This coexistence of different industrial models may ease the creation of advantages, provided the firm cooperation develops and is organised around a common strategy, only possible within a mesoeconomic approach in which the institutions' role and their regulation are clearly defined.

The other limit has been appointed by De Noronha Vaz et al. (2006) and concerns the learning aptitude of the firms, particularly SMEs, which must be perceived as part of coordination strategies and in a context of structural change. Therefore, firms and nonmarket organisations need to act using interfaces that require social legitimacy at various levels: economic, legal and political. Mainly the peripheral regions, where development is an urgent issue, deal with inflexibilities at all those levels.

\section{A contribution: the interface between theory and practice}

\subsection{Modelling firms' behaviour towards innovation as an input to knowledge basis enlargement}

Various interfaces have been created, helping firms to combine sources of technical know-how and information. Sometimes they organise institutional local networks, which help by creating cohesion or a favourable context for innovation. Such cohesion may be represented as a proximity which is more institutional than geographical. In such contexts, learning becomes more urgent than ever and new concepts of exchanges are called for both at firm's level and in the local society. From this starting position to the 
recent effort in understanding the learning process at local level, much has been achieved (Dosi and Marengo, 2000). In any case, the complexity of learning is huge, the instruments to enlarge the knowledge basis are disperse, the innovation phenomenon is complex. Figure 1 is an essay to systematise this framework.

Figure 1 The firms' behaviour towards innovation as an input to knowledge base enlargement

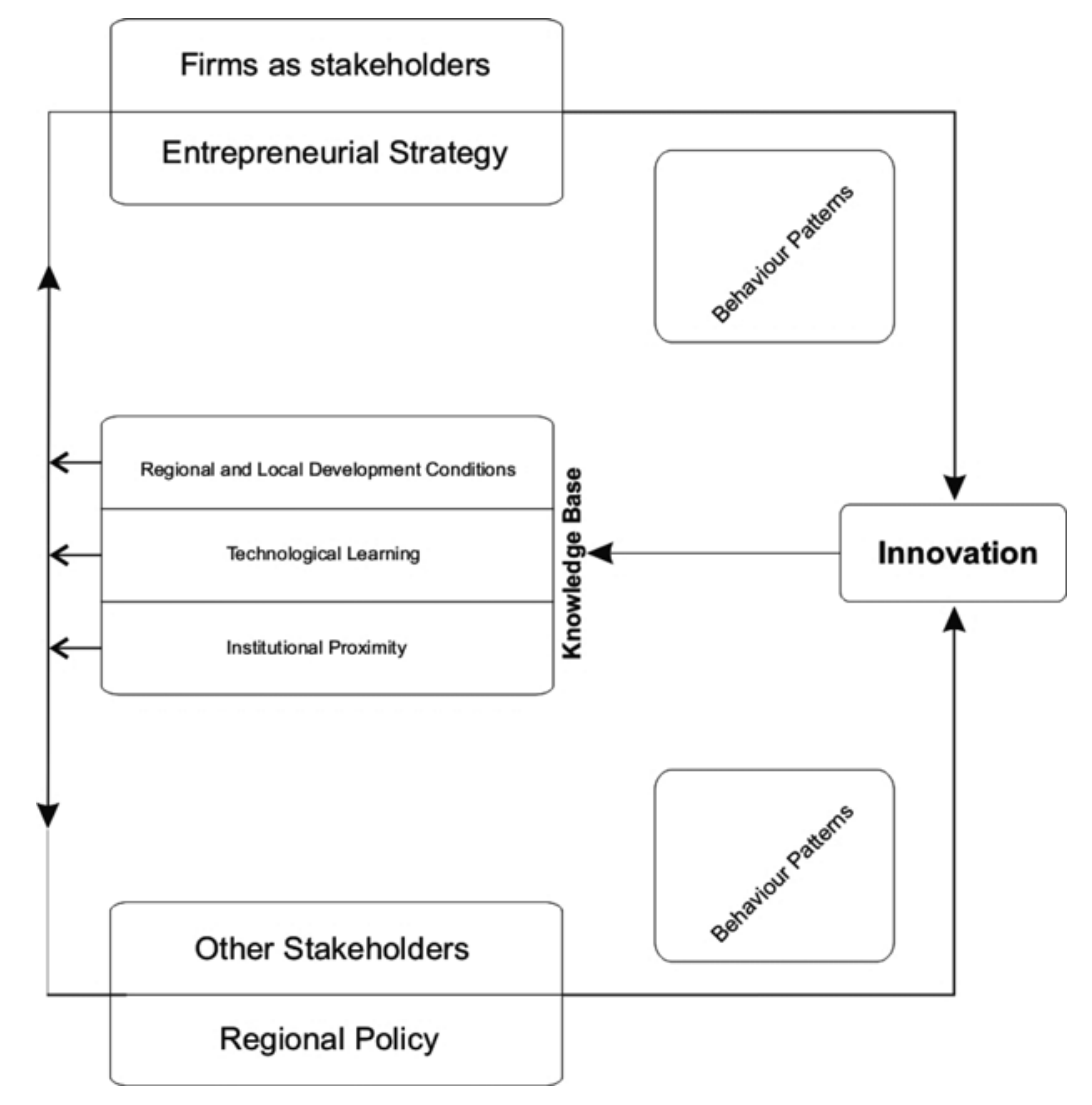

In spite of the extensive bibliography presented during the last decade about regional development and the capacity of locals to create knowledge and improve innovation, there are difficulties in identifying the respective determinant conditions. Checking them, evaluating their efficiency and measuring the real effects of public policies to encourage development and innovation at local level are a challenge.

Wright (1997) justified the weak results of public policy due to the fact that innovating activities do not match with uncertainty reduction, quite on the contrary. This is a stress to be surmounted in the case of small firms that, in general, fit better in the flexible specialisation model. It is therefore pertinent to look for models that make the synthesis of recent theoretical advances and simultaneously are able to suggest adequate proposals of regional development policies on bases of a quantitative appreciation of the determinants of innovation or knowledge creation or learning. 
Our paper deals with such concerns. It aims to develop a method able to model a cause-effect relationship in different firms' behavioural groups between innovation and their determinants, considering them as related to local development conditions, technological learning, institutional proximity and firm strategy. Those determinants are arising from the earlier discussed theoretical framework.

\subsection{Interacting for innovation}

The first assumption of the suggested model (De Noronha Vaz, 2004) is based upon the key role of the small firm for regional development. In this case, regions of NUTS2 dimension were considered for obtaining data.

The second assumption follows Acs (Acs and Audretsch, 1984; Acs, 2002) in recognising industrial innovation as the driving force behind long-run regional growth and accepting that technology and entrepreneurship may foster and promote growth at local level.

The third assumption is related to the complexity of the process of innovation which, however, challenges experts to identify, classify, quantify and model its determinants.

The fourth assumption adopts a broad definition of innovation (Community Innovation Survey). It accepts that this is a multidimensional concept; its measurement is particularly problematic in low technology industries, where it is generally recognised that R\&D activities; and patent data will not provide good proxies for innovation.

According to Lundvall (1995), "innovation is an ongoing process of learning, searching and exploring, which results in new products, new techniques, new forms of organisation and new markets". In the light of this, three main types of innovation were included in this model: product innovation, organisational innovation and marketing innovation.

As it can be observed in Figure 2, the capacity for innovation may result from both trends: (1) influences generated at the level of a simple activity branch that may tend to more complex technological regimes of cooperation or (2) simpler forms of regional growth in which firms could choose to coordinate into more complex inter-territorial systems of institutional cooperation. These trends are represented in the horizontal and vertical axes of the represented model. Each innovative process pulls the firm to a positioning that moves continuously from the bottom to the top and from the left to the right side of figure, changing accordingly the combination of determinants for future innovative choices.

\section{Material and methods}

Based on the theoretical framing, this model considers four sets of innovation drivers, as shown in Figure 2: local development conditions, technological learning, institutional proximity and firm strategy. 
Figure 2 Interacting for innovation

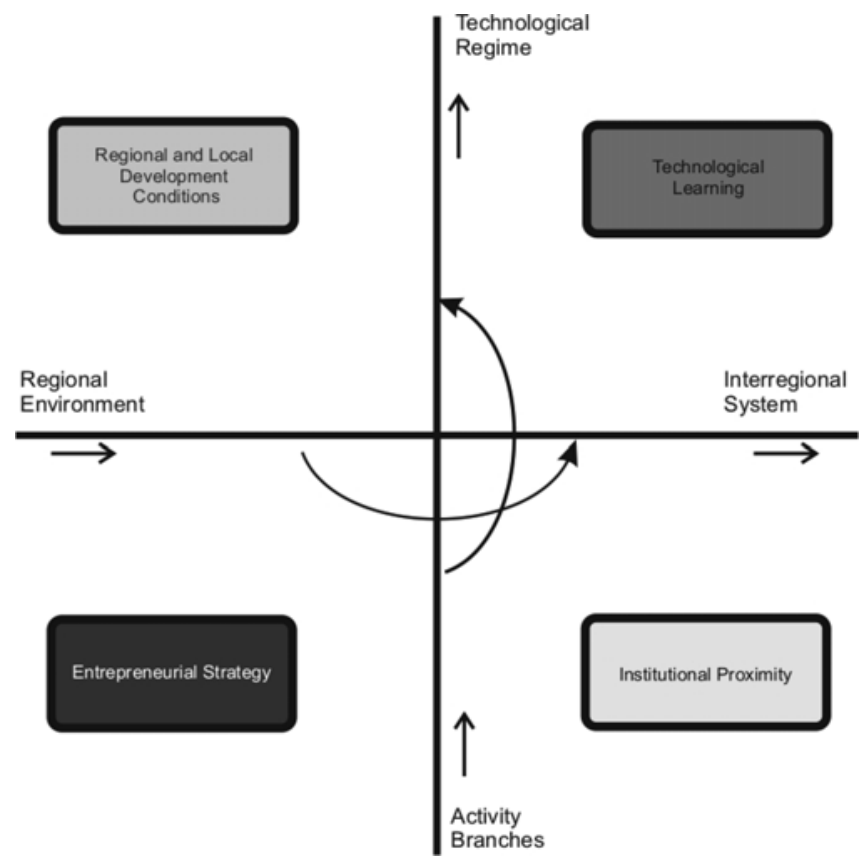

Source: Own elaboration based on De Noronha Vaz et al. (2006)

The sample is composed of 323 firms located in 11 rural regions distributed by six European countries: Belgium, France, Ireland, Poland, Portugal and the UK. These regions are Nuts II or III to easier allow dealing with the secondary data facilitated by local or national organisations: national institutes of statistics, local authorities, chambers of commerce and food associations. The selected regions are Hainaut, West Flanders, Aude, Gard, Border, South West, Kuzawsko-Pomorskie, Alentejo Central, Oeste, Devon and Cornwall, Hereford and Worcs - all of them are rural areas.

The firms belong to the food and drink industry and have small dimension, between 3 and 49 employees. We have used stratified sampling methods to create three bands of 3-9, 10-19 and 20-49 employees' groups in order to have a size distribution matching with the population size distribution.

Different data sources have been used: primary data provided information on firms' activities and respective technical skills as well as internal firm organisational choices and efficiency; secondary data permitted to evaluate regional conditions for local development: per capita regional production, gross added value, active population, employment, number of firms in different sectors and different household expenditures. This data have been collected for the period 1994-1997.

The questionnaires comprehended several sections: an overview of the firms; the Top Manager's (TM's) characteristics; the history and the profile of the firm; manpower and training; products and processes and the changes in these; the forms of intercompany relationships; relationships with support bodies; and other aspects of the regional environment. 
The fieldwork interviews were carried out during a year under rigorous implementation criteria: pilot interviews were made; sociologists addressed the questions to the firms' managers; translation of the questionnaire in all the used languages was made; obtained data were controlled by phone.

The resulting database is a proxy for the different variables discussed in Figure 1, namely, those we have called: variables of entrepreneurial strategy, variables of coordination systems and institutions, variables of technological learning and variables of local development conditions, as referred and described in Appendix 1.

Much of the effort to calculate and measure innovation was put in its definition. Following the approach used in the Community Innovation Survey, a broad definition of innovation was adopted here, so that simple changes, which were new to the firm, were accepted as 'innovation'. Also, according to Lundvall's (1995) multidimensional concept of Innovation, ${ }^{2}$ it was decided to cover three types of innovation: product innovation (I1), organisational innovation (I2) and marketing innovation (I3).

The constructed innovation indices are measured by a specific composition of variables obtained from the group of responses within the questionnaires. Note that the variables defining innovation were constructed as weighted combinations of variables. Diederen et al. (2000) proposed the Delphy method to support the construction of such composed indexes. The original variables were available from the inquiry. Table 1 describes their meaning, representing them by type and code.

Table 1 Endogenous variables

\begin{tabular}{|c|c|c|c|}
\hline Variable & Description & $\begin{array}{l}\text { Type of } \\
\text { variable }\end{array}$ & Coding \\
\hline NewProd & $\begin{array}{l}\text { New or substantially modified } \\
\text { products }\end{array}$ & Dummy & $\begin{array}{l}1 \text { if innovation; } 0 \\
\text { otherwise }\end{array}$ \\
\hline NewIng & Product innovation: new ingredients & Dummy & $\begin{array}{l}1 \text { if innovation; } 0 \\
\text { otherwise }\end{array}$ \\
\hline NewPack & $\begin{array}{l}\text { Product innovation: new packing } \\
\text { material }\end{array}$ & Dummy & $\begin{array}{l}1 \text { if innovation; } 0 \\
\text { otherwise }\end{array}$ \\
\hline NewVisual & Product innovation: visual appearance & Dummy & $\begin{array}{l}1 \text { if innovation; } 0 \\
\text { otherwise }\end{array}$ \\
\hline Newness & $\begin{array}{l}\text { When new products are introduced, } \\
\text { how often are they also new to the } \\
\text { market }\end{array}$ & Categorical & $\begin{array}{l}\text { In bands, up to } 4 \\
\text { (always) }\end{array}$ \\
\hline Turnover & $\begin{array}{l}\text { Percentage of turnover due to new } \\
\text { products }\end{array}$ & Categorical & $\begin{array}{l}\text { In bands, up to } 5 \\
(21 \%+)\end{array}$ \\
\hline OrgMang & Organisational change in management & Dummy & $\begin{array}{l}1 \text { if innovation; } 0 \\
\text { otherwise }\end{array}$ \\
\hline OrgMark & $\begin{array}{l}\text { Organisational change in marketing } \\
\text { structure }\end{array}$ & Dummy & $\begin{array}{l}1 \text { if innovation; } 0 \\
\text { otherwise }\end{array}$ \\
\hline OrgFin & $\begin{array}{l}\text { Organisational change in financial } \\
\text { structure }\end{array}$ & Dummy & $\begin{array}{l}1 \text { if innovation; } 0 \\
\text { otherwise }\end{array}$ \\
\hline OrgOper & $\begin{array}{l}\text { Organisational change in production } \\
\text { operations }\end{array}$ & Dummy & $\begin{array}{l}1 \text { if innovation; } 0 \\
\text { otherwise }\end{array}$ \\
\hline OrgLog & $\begin{array}{l}\text { Organisational change in logistics } \\
\text { management }\end{array}$ & Dummy & $\begin{array}{l}1 \text { if innovation; } 0 \\
\text { otherwise }\end{array}$ \\
\hline OrgOth & $\begin{array}{l}\text { Organisational change in other } \\
\text { functional areas }\end{array}$ & Dummy & $\begin{array}{l}1 \text { if innovation; } 0 \\
\text { otherwise }\end{array}$ \\
\hline
\end{tabular}


Some comments should be added in order to decrease the restrictions related to the use of this technique. The number of experts for the Delphy study can always be reinforced, decreasing the risk of deviations in the weights attributed to the different exogenous variables. Also, simulations can provide increasing reliable results. And, finally, the formulations for the existent questions can be improved. Thus, it is expected that the expressed relations should adjust to new environmental conditions and technical changes; in case they do not, simulative scenarios should serve for improved methods. Under such assumption, we accept the following system of simultaneous equations to reflect static patterns of innovation for the considered groups of firms:

$$
\begin{aligned}
& I_{1}=\alpha_{1} \text { NewProd }+\alpha_{2} \text { NewIng }+\alpha_{3} \text { NewPack }+\alpha_{4} \text { Newness }+\alpha_{5} \text { Turnover, } \\
& \text { with } \sum_{i=1}^{5} \alpha_{i}=1 \\
& I_{2}=\beta_{1} \text { OrgMan }+\beta_{2} \text { OrgMark }+\beta_{3} \text { OrgFin }+\beta_{4} \text { OrgOp }+\beta_{5} \text { OrgLog }+\beta_{6} \\
& \text { OrgOth, with } \sum_{i=1}^{6} \beta_{i}=1 \\
& I_{3}=\delta_{1} \text { NewProd }+\delta_{2} \text { NewVisual }+\delta_{3} \text { OrgMark, with } \sum_{i=1}^{3} \delta_{i}=1
\end{aligned}
$$

\section{Analyses}

The application of a multivariate statistical analysis and linear regression methods resulted in a possibility to model patterns of entrepreneurial behaviour towards innovation.

To the initial database matrix a filter reduced the available variables for cluster analysis, applied to the 388 observations. The classification of different behavioural patterns (see Appendix 2) determined by the three composed endogenous variables of innovation $\left(\mathrm{I}_{1}, \mathrm{I}_{2}, \mathrm{I}_{3}\right)$ are shown in Table 2, as following:

- Multiple innovators: The group comprehends 175 firms which carry out product as well as marketing and organisational innovation. All the regions are represented amongst this group but relatively few of them are found in Gard, Alentejo Central and West Flanders.

- Non-innovators: This second largest group, composed of 84 firms, represents firms that do not innovate. These firms are mainly located in Alentejo Central, Southwest and West Flanders.

- Focused innovators: The last two groups of firms are of approximately the same size and add up 64 firms. The similar behavioural patterns are characterised by frequently developed product innovation and some efforts towards new forms of marketing. The global intensity of innovative performances varies significantly among the two groups - English, Irish and Polish firms belong to the more innovative cluster. 
Table 2 Clustering and firms' regional location

\begin{tabular}{lcccc}
\hline Clusters & $\begin{array}{c}\text { Multiple } \\
\text { innovators }\end{array}$ & Non-innovators & $\begin{array}{c}\text { Focused } \\
\text { innovators low }\end{array}$ & $\begin{array}{c}\text { Focused } \\
\text { innovators high }\end{array}$ \\
\hline Aude & 20 & 5 & 4 & 1 \\
Gard & 8 & 9 & 11 & 2 \\
Devon/Cornwall & 17 & 2 & 5 & 6 \\
Heref/Worcester & 17 & 3 & 2 & 8 \\
Oeste & 14 & 7 & 1 & 0 \\
Alentejo Central & 11 & 17 & 2 & 0 \\
Southwest & 15 & 10 & 1 & 4 \\
Border & 18 & 9 & 1 & 2 \\
West Flanders & 12 & 11 & 2 & 4 \\
Hainaut & 20 & 3 & 2 & 1 \\
Kuzawsko-Pomorskie & 23 & 8 & 0 & 5 \\
Total & 175 & 84 & 31 & 33 \\
\hline
\end{tabular}

Linear regression was used to search for the determinants of the different patterns of entrepreneurial behaviour towards innovation. In Table 3, the explanatory power of the estimated equations is specified - in certain cases it is quite weak. For example, product innovation is poorly explained by the variables picked up in the model for the group of multiple innovators. The explanatory power slightly improves in quality when both marketing and organisational innovation are being considered for the same group.

Table 3 Explanatory power of the regression functions

\begin{tabular}{lccccc}
\hline$R^{2}$ & $\begin{array}{c}\text { Type of } \\
\text { innovation }\end{array}$ & $\begin{array}{c}\text { Cluster 1 } \\
\text { (175 elements) }\end{array}$ & $\begin{array}{c}\text { Cluster 2 } \\
\text { (84 elements) }\end{array}$ & $\begin{array}{c}\text { Cluster 3 } \\
\text { (31 elements) }\end{array}$ & $\begin{array}{c}\text { Cluster 4 } \\
\text { (33 elements) }\end{array}$ \\
\hline $\begin{array}{l}\text { Product } \\
\text { innovation }\end{array}$ & $\mathrm{I}_{1}$ & 0.197 & $\mathbf{0 . 5 9 3}$ & $\mathbf{0 . 6 8 6}$ & not obtained \\
$\begin{array}{l}\text { Organisational } \\
\text { innovation }\end{array}$ & $\mathrm{I}_{2}$ & 0.337 & 0.365 & $\mathbf{0 . 7 7 2}$ & $\mathbf{0 . 7 0 2}$ \\
$\begin{array}{l}\text { Marketing } \\
\text { Innovation }\end{array}$ & $\mathrm{I}_{3}$ & 0.388 & $\mathbf{0 . 6 0 2}$ & 0.171 & 0.411 \\
\hline
\end{tabular}

The result for marketing innovation in the case of the less performing focused innovators is also disappointing. In other cases, the $R^{2}$ is reasonable. The fact that the $R^{2}$ for the group of more innovative firms is lower suggests that the set of variables included in this study may have omitted some of the important aspects related to innovation, since this is taking place in a multidimensional strategic context.

Considering the different types of innovation, organisational innovation is the one for which the relationships are best defined by the presented estimations.

Many of the results of this table have a direct relation with the quality of the proposed variables expressed by the questionnaire. Although this method might become very useful, some refinements are due: a revision and adaptation of the questionnaire, as well as a clarification on the definition of the different types of innovation. For future studies, such adequate adjustments would, certainly, improve the fitness of this model. 


\section{Results}

The exogenous variables most closely associated with the three different forms of innovations - product, organisational and marketing innovation - were identified from the subsequent regression analyses. Some are related to internal characteristics of the firms and some to external factors; however, most of them are related to direct or indirect forms of learning.

The use of regression analyses determined linear regression models able to define the sets of explicative functions for the endogenous innovation variables within each behavioural pattern of firms. The regressions followed the stepwise method to quantitatively define the groups' behaviour and evaluate their impact upon each of the predefined clusters.

The following equations settle the behavioural patterns for firms relative to the innovative attitudes in the different regions and countries. In order to facilitate understanding, the Annex 1 supplies a list of all the used variables.

The main general conclusion resulting from the regression analyses indicates that the determinants of each type of innovation change with the behavioural pattern in which firms are included. There is a certain national outline in such patterns, confirming the influence of national innovation systems: group I is mainly constituted by French and Belgium firms; group II, by British, Irish and Portuguese (from Alentejo) ones; small firms from group III have origin in Italy and Portugal (from Oest region); and finally, those from Poland characterise the group IV.

The results indicate that for the group of multiple innovators, product innovation is a less complex phenomenon than marketing or organisational innovation. The respective determinants seem to be directly related with local development conditions. While organisational and marketing innovation rise in such firms, essentially, when those conditions are linked to institutional proximity, it is also interesting to note that the longer the TM stays active in the firm, the less crucial he becomes to introduce innovative processes or products (see Table 4).]

There are other unexpected conclusions. For example, the increase in expenses in R\&D does not necessarily create product innovation. But, when combined with external factors such as governmental assistance, it is fundamental for organisational innovation to take place. Also, to note that research institutions have a negative impact upon marketing innovation, which seems to be positively affected by consumption increases, intellectual property and other external factors such as existence of consultants or ICTs.

In general, for this group, innovation is mostly determined by local conditions for consumption, employment and institutional proximity.

When comparing the determinants of innovation between multiple innovators and non-innovators, several differences in the set of determinants may be found. Namely, that for non-innovators institutional proximity leading to networking is scarce and with positive effect only upon organisational and marketing innovation. For this group of firms, product innovation is a result of productivity in services, education of the TM and expenses in R\&D. 
Table 4 The determinants of innovation for multiple innovators

\begin{tabular}{|c|c|c|c|c|}
\hline Dependent Variable & $\begin{array}{l}\text { Exogenous variables by group of } \\
\text { determinants }\end{array}$ & St. Coeff. & $t$ & Sig. \\
\hline \multirow[t]{3}{*}{ Product innovation } & $\begin{array}{l}\text { Top Manager - number of years } \\
\text { active in the enterprise }\end{array}$ & -0.258 & -3.655 & 0.000 \\
\hline & \% Expenditures on drinks (1994) & 0.268 & 3.799 & 0.000 \\
\hline & \% Employment in industry (1997) & 0.167 & 2.437 & 0.016 \\
\hline \multirow[t]{8}{*}{ Organisation innovation } & IRP per capita (1997) & -0.302 & -4.549 & 0.000 \\
\hline & \% Turnover spent on R\&D in 2000 & 0.224 & 3.392 & 0.001 \\
\hline & $\begin{array}{l}\text { External factors region - similar } \\
\text { enterprise }\end{array}$ & -0.332 & -4.691 & 0.000 \\
\hline & External factors - overall & 0.445 & 5.868 & 0.000 \\
\hline & $\begin{array}{l}\text { Top Manager - number of years } \\
\text { active in the enterprise }\end{array}$ & -0.133 & -1.998 & 0.047 \\
\hline & External factors - customers & -0.195 & -2.694 & 0.008 \\
\hline & $\begin{array}{l}\text { \% Expenditures on outside meals } \\
(1997)\end{array}$ & -0.165 & -2.347 & 0.020 \\
\hline & Governmental assistance: national & 0.132 & 1.988 & 0.048 \\
\hline \multirow[t]{6}{*}{ Marketing innovation } & $\%$ Expenditures on drinks (1994) & 0.347 & 5.617 & 0.000 \\
\hline & Intellectual property & 0.210 & 3.346 & 0.001 \\
\hline & $\begin{array}{l}\text { External factors region - research } \\
\text { institution }\end{array}$ & -0.193 & -3.098 & 0.002 \\
\hline & External factors - overall & 0.490 & 5.355 & 0.000 \\
\hline & External factors - research institution & -0.343 & -3.739 & 0.000 \\
\hline & $\begin{array}{l}\text { External factors region- equipment } \\
\text { suppliers }\end{array}$ & -0.156 & -2.484 & 0.014 \\
\hline
\end{tabular}

Note:

\begin{tabular}{|l|l|}
\hline & Institutional proximity \\
\hline & Local development conditions \\
\hline & Technological learning \\
\hline & Entrepreneurial strategies \\
\hline
\end{tabular}

For non-innovators, the variables related to technological learning are of utmost importance (Table 5).

As earlier pointed out, focused innovators are the companies performing basically only one type (or two, occasionally) of innovation with lower or higher performance rates. When comparing this kind of innovators with multiple innovators, there is a clear difference in the level of simplicity of the respective determinants - the results suggest that the set of determinants of innovation is smaller. 
Table 5 The determinants of innovation for non-innovators

\begin{tabular}{llccc}
\hline \multirow{2}{*}{ Dependent Variable } & $\begin{array}{l}\text { Exogenous variables by group of } \\
\text { determinants }\end{array}$ & St. Coeff. & $t$ & Sig. \\
\hline Product innovation & Productivity in services (1994) & 0.979 & 9.732 & 0.000 \\
& \% Employment in industry (1994) & -0.321 & -3.732 & 0.000 \\
& \% Turnover spent on R\&D in 2000 & 0.193 & 2.583 & 0.012 \\
& Productivity in services (1997) & -0.304 & -3.595 & 0.001 \\
& Educational qualification of the TM & 0.253 & 3.242 & 0.002 \\
& - college certificate & & & \\
& External factors region - equipment & -0.184 & -2.236 & 0.028 \\
& suppliers & & & \\
\hline Organisation innovation & External factors - research institution & 0.393 & 4.257 & 0.000 \\
& Training carry out - types & 0.301 & 3.194 & 0.002 \\
& IRP per capita (1994) & -0.351 & -3.207 & 0.002 \\
& \% Employment in services (1997) & 0.234 & 2.120 & 0.037 \\
\hline Marketing innovation & Productivity in services (1994) & 0.840 & 7.316 & 0.000 \\
& External factors - customers & 0.230 & 2.782 & 0.007 \\
& \% Employment in industry (1994) & -0.267 & -2.954 & 0.004 \\
& \% Turnover spent on R\&D (2000) & 0.205 & 2.702 & 0.009 \\
& Productivity in industry (1997) & -0.266 & -2.775 & 0.007 \\
& Intellectual property & 0.185 & 2.445 & 0.017 \\
& \% Technical qualified labour in 2000 & -0.169 & -2.147 & 0.035 \\
\hline
\end{tabular}

Note:

\begin{tabular}{|l|l|}
\hline & Institutional proximity \\
\hline & Local development conditions \\
\hline & Technological learning \\
\hline & Entrepreneurial strategies \\
\hline
\end{tabular}

As can be observed from Tables 6 and 7, low performers depend almost exclusively on the quality of labour and on some one or other variables of technological learning. On the contrary, high performers focused innovators act innovatively mostly when entrepreneurial strategies are taking place, namely, to increase the number of employees.

The high performance focused innovators do not integrate, in general, product innovation. They concentrate their innovativeness in the marketing or organisational processes. Only in these cases significant values were detected related to firms' dimension. The explanation may be found in the fact that size matters in order to allow the introduction of new tasks and their reordering or specialisation. This may be the reason why also information and technology specialists as well as the training carried out of the firm have been detected as further factors constituting sources for innovative initiatives.

For this group, it was possible to have a reasonable understanding from the mechanism behind marketing innovation, particularly in what concerns focused innovators. The number of workers and their qualification justified it in the case of high performers and regional productivity, in the case of low performers. 
Table 6 The determinants of innovation for focused innovators with low performance

\begin{tabular}{llccc}
\hline \multirow{2}{*}{ Dependent variable } & $\begin{array}{l}\text { Exogenous variables by group of } \\
\text { determinants }\end{array}$ & St. Coeff. & $t$ & Sig. \\
\hline Product innovation & \% High qualified Labour (1997) & 0.737 & 6.704 & 0.000 \\
& Intellectual property & 0.379 & 3.410 & 0.002 \\
& Area of qualification of the TM: & 0.337 & 3.085 & 0.005 \\
& business/economics & & & \\
\hline Organisation innovation & \% Turnover spent on R\&D in 2000 & 0.543 & 4.887 & 0.000 \\
& External factors - overall & 0.443 & 3.981 & 0.000 \\
\hline Marketing innovation & Productivity (1994) & -0.414 & -2.449 & 0.021 \\
\hline
\end{tabular}

Note:

\begin{tabular}{|l|l|}
\hline Institutional proximity \\
\hline & Local development conditions \\
\hline & Technological learning \\
\hline & Entrepreneurial strategies \\
\hline
\end{tabular}

Table 7 The determinants of innovation for focused innovators with high performance

\begin{tabular}{|c|c|c|c|c|}
\hline Dependent variable & $\begin{array}{l}\text { Exogenous variables by group of } \\
\text { determinants }\end{array}$ & St. Coeff. & $t$ & Sig. \\
\hline \multirow[t]{3}{*}{ Organisation innovation } & $\begin{array}{l}\text { People normally working in the } \\
\text { business in } 2000\end{array}$ & 0.608 & 4.985 & 0.000 \\
\hline & $\begin{array}{l}\text { External factors region - IT } \\
\text { specialists }\end{array}$ & 0.322 & 2.728 & 0.011 \\
\hline & Training carry out & 0.229 & 2.125 & 0.043 \\
\hline \multirow[t]{2}{*}{ Marketing innovation } & $\begin{array}{l}\text { People normally working in the } \\
\text { business in } 2000\end{array}$ & 0.478 & 3.406 & 0.002 \\
\hline & $\begin{array}{l}\text { \% Secondary level qualified labour } \\
\text { (1997) }\end{array}$ & 0.454 & 3.234 & 0.003 \\
\hline
\end{tabular}

Note:

\begin{tabular}{|l|l|}
\hline & Institutional proximity \\
\hline & Local development conditions \\
\hline & Technological learning \\
\hline & Entrepreneurial strategies \\
\hline
\end{tabular}

\section{Conclusion}

Our paper brings up to scene some conclusions regarding the nature of innovation as well as the complexity of its determinants:

1 Firstly, it demonstrates the irregularity of cause-effect conditions to generate innovation. The fact that, in a reduced sample of European firms, it was possible to find four distinct behavioural patterns of innovative companies explains the microeconomic bases of this issue. 
2 Secondly, a clear national trace could be identified, meaning that also national innovation systems have a clear impact on how companies act and develop their skills regarding innovation.

3 Thirdly, although assuming the complexity of innovation it was not expected that, after having started the model with a very large number of exogenous variables, the analytical procedure would reduce significantly the amount of significant ones.

4 Finally, it is also of major importance to recognise that even though entrepreneurial strategies determine innovation, an isolated microeconomic basis for analyses is clearly insufficient to explain companies' aptitude to produce new products and processes. Indeed, in the sample, those variables related to technological learning demonstrated to play a direct role in the increase of innovation in the small firms. The percentage of the turnover expended in the R\&D activities, training carried out in the firms, technical qualification of the TMs and intellectual property confirmed to be permanent determinants for all the groups, even if the respective influence upon innovation varies from group to group.

It is necessary to clarify that both groups of determinants related to institutional proximity and technological learning may be confusing as they result from closely connected concepts. In practice, such determinants may be facilitated by some specific requirements that firms' suppliers and/or clients impose to small firms. This is frequent when companies have difficulties in innovating, as it is the case of non-innovators. External exchanges, as referred by the theory, are of utmost significance, challenging to more accurate analyses but within a mesoeconomic context.

We were also able to define the importance of macroeconomic conditions as an input to firms' attitudes towards innovation. Considering the results, factors related to regional growth, such as regional productivity, household expenses or labour force qualification, were associated to certain forms of innovation, independently of the behavioural patterns followed by the firms.

Still, these variables have puzzling effects due to direct and indirect correlations. In many cases, direct impacts do not occur as expected, showing inconsistent relations between innovation and regional growth, consumption or market competition. No doubt that further similar exercises and simulations are needed to shed light on the links between all the four groups of determinants that have been proposed in our initial model: local development conditions, technical learning, entrepreneurial strategies and institutional proximity.

Another important conclusion arising from this study regards the idea of direct financing to firms or the need for increasing support for information technologies. The model indicates that such measures have impacts only upon marketing innovation and this just in the case of good performers. The same kind of very restrictive, positive impacts occur when considering any sort of governmental assistance: the reduced positive impact is specific to marketing innovation and was observed only in the case of multiple innovators.

So far, we also would conclude that for multiple innovators, our most dynamic group, internal consumption is a determinant factor to generate product innovation, while institutional proximity and networking are driving forces for organisational innovation.

The proposed model aims to be dynamic. Besides, the fact that the empirical analysis does not include different observation periods hinders such goal. Further research is 
required in order to verify future trends for the determinants of innovation and to confirm future tendencies for the formation of complex technological regimes, eventually strengthening inter-territorial systems, as previously pointed out.

The developments resulting from this work represent a step in proving the possibilities to measure and evaluate the nature and links of innovation. In presence of such a highly complex task, the introduced quantitative methods are limited. Further improvements to this methodology such as those suggested earlier in the text would add important tools for analyses. The fact that determinants of innovation have been classified and aggregated, creating a linkage between them and firms' behavioural patterns, is, in any case, a significant contribution for regional policy.

\section{Acknowledgements}

We are thankful to the anonymous reviewer, whose comments were valuable contributions to improve the quality of this study.

\section{References}

Acs, Z. (2002) Innovation and Growth of Cities, Edward Elgar, UK.

Acs, Z. and Audretsch, D.B. (1984) 'Small business in industrial economics: the new learning', Revue d'Economie Industrielle, Vol. 67, pp.21-39.

Amin, A. and Cohendet, P. (1999) 'Learning and adaptation in decentralised business network', Environment and Planning D: Society and Space, Vol. 17, pp.87-104.

Antonelli, C. (1995) 'Économie des Réseaux: variété et compléntarité', in: Ralllet, A. and Torre, A. (Eds): Économie Industrielle et Économie Spatiale, Economica, Paris, pp.25-72.

Aydalot, P. (1984) 'La crise économique et l'espace: recherche sur les nouveaux dynamismes spatiaux', Review Canadienne des Sciences Régionales, Vol. 7, No. 1, pp.9-31.

Camagni, R. (1991) Innovation Networks: Spatial Perspectives, Belhaven Press, London.

Clark, G. and Tracey, P. (2004) Global Competitiveness and Innovation: An Agent Centred Perspective, Palgrave Macmillan, UK.

Cooke, P., Uranga, M.C. and Etxebarria, G. (1998a) 'Regional systems of innovation: institutional and organisational dimensions', Research Policy, Vol. 26, pp.475-491.

Cooke, P., Uranga, M.C. and Etxebarria, G. (1998b) 'Regional systems of innovation: an evolutionary perspective', Environment and Planning A, Vol. 30, pp.1563-1584.

Crevoisier, O. (2001) 'L'approche des milieux innovateurs: état des lieux et perspectives', Revue d'Économie Régionale et Urbaine, Vol. 1, pp.153-165.

De Noronha Vaz, M.T. (2004) 'The environmental context for small firms in the EU', in Vaz et al. (Eds): Innovation in Small Firms and Dynamics of Local Development, Scholar Pub. House, Warsaw, pp.13-31.

De Noronha Vaz, M.T. (2007) 'The design of industrial models', in Desai, S., Stough, R. and Nijkamp, P. (Eds), Entrepreneurship and Innovation: A Spatial Perspective, Edward Elgar, Cheltenham, (accepted).

De Noronha Vaz, M.T., Cesário, M. and Fernandes, S. (2006) 'Interaction between innovation in small firms and their environments: an exploratory study, special issue: rural development, European Planning Studies, Vol. 14, No. 1, pp.95-117.

Diederen, P., Van Meijl, H. and Wolters, A. (2000) Eureka! Innovatieprocessen en innovatiebeleid in de land-en tuinbouw, Report Den Haag, LEI. 
Dosi, G. and Marengo, L. (2000) 'On the tangled discourse between transaction cost economics and competence-based view of the firm', in Foss, N. and Mahnke, V. (Eds): Competence, Governance, and Entrepreneurship, Oxford University Press, Oxford, pp.80-94.

Fischer, M.M. and Johansson, B.(1993) 'Networks for process innovation by firms: conjectures from observations in three countries', in Johansson, K. (Ed.): Patterns of a Network Economy, Springer-Verlag, p.315.

Gabolde, J. (1997) Second European Report on S\&T Indicators, European Commission, Brussels.

Gallego, J.R. (1997) Cambio Tecnológico Y Transformación De Sistemas Industriales Localizados: El Caso De La Industria Española De Pavimentos Y Revestimientos Cerámicos, Tesis Doctoral, Universitat de Valencia, Mimeo.

Gallego, J.R. (2003) 'Relaciones entre sistema científico-tecnológico y sistema productivo en sistemas sectoriales-regionales de producción y de innovación. Aplicación a la citricultura valenciana', Reunión Asepelt, Vol. 17, Almería.

Grosjean, N. and Crevoisier, O. (1998) Systemes de Production Territoriaux: vers une Methode systematique d'identification et d'evaluation, Université de Neuchâtel.

Keeble, D. (1997) 'Small firms, innovation and regional development in Britain in the 1990s', Regional Studies, Vol. 31, No. 3, pp.281-293.

Landabaso, M. (1997) 'The promotion of innovation in regional policy: proposals for a regional innovation strategy', Entrepreneurship \& Regional Development, Vol. 9, No. 1, pp.1-24.

Lundvall, B-A. (Ed.) (1992) National Systems of Innovation: An Analytical Framework, Printer Publishers, London.

Lundvall, B-A. (1995) National Systems of Innovation; Towards a Theory of Innovation and Interactive Learning, London.

Lundvall, B-A. and Johnson, B. (1994) 'The learning economy', Journal of Industry Studies, Vol. 2, pp.23-42.

Maillat, D. (1998) 'From the industrial district to the innovative milieu: contribution to an analysis of the territorialised productive organisation', Recherches Économiques de Louvain, Vol. 64, No. 1, pp.111-129.

Ménard, C. (2000) Institutions, Contracts and Organizations, Edward Elger, UK, p.458.

Nelson, R. and Winter, S. (1982) An Evolutionary Theory of Economic Change, Harvard University Press, Cambridge.

Storper, M. (1997) The Regional World, Guilford Press, New York.

Torre, A. and Gilly, J-P. (2000) 'On the analytical dimension of proximity dynamics', Regional Studies, Vol. 34, No. 2, pp.169-180.

Wright, G. (1997) 'Towards a more historical approach to technological change', The Economic Journal, Vol. 107, pp.1560-1566.

\section{Notes}

1 Le Groupe de Recherche Européen sur les Milieux Innovateurs.

2 An ongoing process of learning, searching, and exploring which results in new products, new techniques, new forms of organisation and new markets. 


\section{Appendix 1 List of exogenous variables}

\section{Variables of technological learning}

Internal factors of innovation

1 Technological resources

- R\&D expenses as \% of turnover in 2000

- ownership of intellectual property - patents, licences, registered brands or designs (binary variable, where 1 indicates ownership).

2 Skills of the workforce

- number of specialised workers, with managerial or technical functions

- proportion of the previous staff categories in the total workforce

- presence or absence of training in 2000 (binary variable, 1 indicates presence)

- types of training carried out: technical, marketing, information technologies, food safety and hygiene (variable ranging from 0 to 4 , where 4 indicate all four types of training).

3 Education of the Top Manager (TM)

- first-level school completion certificate (binary variable, 1 indicates completion)

- second-level school completion certificate (binary variable, 1 indicates completion)

- university bachelor, graduation or master's degree (binary variable, 1 indicates completion)

- post-school qualification in business or economics (binary variable, 1 indicates qualified)

- post-school qualification in technology or engineering (binary variable, 1 indicates qualified).

\section{Variables of entrepreneurial strategy}

1 Characteristics of the enterprise

- size of the enterprise (number of employees)

- age of the enterprise.

2 Profile of the TM

- age of the owner/TM (variable divided into the following intervals: $<29,30-39$, $40-49,50-59,60-69,>70$ )

- number of years active in the enterprise

- number of years as the TM

- owner inherited the enterprise or purchased from family (binary variable, 1 indicates inherited or purchased) 
- $\quad$ experience in a similar business (binary variable, 1 indicates such experience)

- owner is from region (binary variable, 1 indicates from region)

\section{Variables of institutional proximity}

\section{External factors of innovation}

- Use of inputs for developing R\&D activities or product/process/organisational innovations. These may come from 6 types of external agents: equipment suppliers, material suppliers, customers, similar enterprises, research institutions, management consultants including IT specialists. (Binary variable for the presence or absence of interaction with each category of external agents and a variable with an interval from 0 to 6 , where 6 indicates inputs from all six categories of agents.)

- Using regional inputs for developing R\&D activities or product/process/ organisational innovations, which come from the same previous categories of external agents according to whether they are located in the same region as the enterprise (variable is defined like the previous one but with 0 if the input is from outside the region).

- Using structures of public support such as funds, subsidies, $R \& D$ grants, promotion of local industries, training support, etc. (Three binary variables for the presence or absence of these supports at the regional, national and European level where 1 indicates presence of such support.)

\section{Variables indicative of local development conditions*}

- internal regional product per capita

- gross added value per person employed

- gross added value per person employed in the primary sector

- gross added value per person employed in the secondary sector

- gross added value per person employed in the tertiary sector

- proportion of active population with secondary level qualifications

- proportion of active population with higher level qualifications

- investments in transports and communications in relation to surface area

- employment in the primary sector as a percentage of total employment

- employment in the secondary sector as a percentage of total employment

- employment in the tertiary sector as a percentage of total employment

- number of enterprises in the primary sector as a percentage of total number of enterprises 
- number of enterprises in the secondary sectors as a percentage of total number of firms

- number of enterprises in the tertiary sector as percentage of total number of enterprises

- $\quad$ expenditure on food as a proportion of household expenditure

- $\quad$ expenditures on drinks as a proportion of household expenditure

- $\quad$ expenditure on meals outside home as a proportion of household expenditure

* Data is available for the years 1994 and 1997.

\section{Appendix 2 Innovative functions: mean values}

Cluster 1

\begin{tabular}{lccc}
\hline & Product innovation & $\begin{array}{c}\text { Organisational } \\
\text { innovation }\end{array}$ & $\begin{array}{c}\text { Marketing } \\
\text { innovation }\end{array}$ \\
\hline N valid & 175 & 175 & 175 \\
Missing & 0 & 0 & 0 \\
Mean & 2.4567 & 0.3571 & 0.6771 \\
\hline
\end{tabular}

Cluster 2

\begin{tabular}{lccc}
\hline & Product innovation & $\begin{array}{c}\text { Organisational } \\
\text { innovation }\end{array}$ & $\begin{array}{c}\text { Marketing } \\
\text { innovation }\end{array}$ \\
\hline N valid & 84 & 84 & 84 \\
Missing & 0 & 0 & 0 \\
Mean & 0.1832 & 0.1210 & 0.1310 \\
\hline
\end{tabular}

Cluster 3

\begin{tabular}{lccc}
\hline & Product innovation & $\begin{array}{c}\text { Organisational } \\
\text { innovation }\end{array}$ & $\begin{array}{c}\text { Marketing } \\
\text { innovation }\end{array}$ \\
\hline N valid & 31 & 31 & 31 \\
Missing & 0 & 0 & 0 \\
Mean & 1.3846 & 0.1183 & 0.5242 \\
\hline & & & \\
Cluster 4 & & Organisational & Marketing \\
\hline & & innovation & 33 \\
\hline N valid & 33 & 33 & 0 \\
Missing & 0 & 0 & 0.6439 \\
Mean & 2.5991 & 0.2121 & \\
\hline
\end{tabular}

